\title{
A survey on attitudes toward control of forest insects
}

\author{
by Heather MacDonald ${ }^{1}$, Daniel McKenney ${ }^{2}$ and Vince Nealis ${ }^{2}$
}

\begin{abstract}
This paper reports a survey of residents of five communities in Ontario about their attitudes to the nature and control of infestations by two forest insect pests; the gypsy moth and the jack pine budworm. The survey results indicate that people feel they are generally familiar with both insects, but gypsy moth is more widely known. Despite the fact that respondents had different experiences with infestations, these differences did not noticeably influence attitudes towards control. Most respondents felt some control action was desirable. A biological pesticide was consistently preferred across all communities, however, respondents from communities affected by gypsy moth were more likely to prefer letting an infestation run its course than respondents from communities affected by jack pine budworm. In contrast, respondents from jack pine budworm communities were more likely to favour any type of pesticide - biological or chemical — than were respondents from gypsy moth communities. Despite widespread preference for the use of $\mathrm{Bt}$, a biological pesticide, people were not willing to pay directly for this or any other management approach as they felt that responsibility for control rested elsewhere. An important underlying message is that if resource managers want the public to differentiate pest management options more critically, information programs likely need to more heavily stress the ecological and economic differences between insects.
\end{abstract}

\section{Introduction and Background}

The use of pesticides on forest lands is a contentious issue. Public opposition has evolved because of an increase in awareness and concern for the environment, as well as fears of health hazards associated with pesticides. In forestry, concerns have been exacerbated by the increased contact of urban and semi-urban communities with forestry activities and with the use of forests for recreational activities. This evolution of public interest and concern has made consultation an important component in developing and implementing forest management plans. Indeed, several of the indicators of sustainable forestry endorsed by the Canadian Council of Forest Ministers (CCFM) stress the need for fair, open, participatory and informed decision-making (CCFM 1995).

Formal surveys or polls can be a valuable tool for judging public attitudes about particular forest management activities and evaluating the effectiveness of public information programs (Miller and Lindsay 1993). When these surveys are designed carefully and the response is adequate, surveys have several advantages over other public forums such as townhall meetings and the news media. Surveys permit a more random and therefore a more representative sample of public opinion. The objectives of the survey can be stated beforehand; the data are then analyzed in a rigorous manner and results interpreted with reference to these objectives.

This paper reports the results of a survey of attitudes of residents of five Ontario communities to aerial application of insecticides to control forest insect pests. Specifically, we wanted to compare the attitudes of residents from communities with recent experience to two very different defoliating insects: the

'Psychology Department Simon, Fraser University, Burnaby, British Columbia V5A IS6 (corresponding author).

${ }^{2}$ Natural Resources Canada, Canadian Forest Service, 1219 Queen Street East, Sault Ste. Marie, Ontario P6A 5M7. jack pine budworm (Choristoneura pinus Freeman) and the gypsy moth (Lymantria dispar L.). Three of the five communities surveyed, Espanola, Dryden and Kenora, had experienced jack pine budworm outbreaks, while the two other communities, Bracebridge and Tweed, had experienced gypsy moth infestations in the past. These five communities are all small to midsize rural towns close to forested lands with populations between two and twelve thousand inhabitants. The more northern communities of Kenora, Espanola and Dryden have economies that are influenced by the state of local forests more directly than Bracebridge and Tweed. This paper focuses on several issues: how aware are people about insect pests; do people feel insect infestations are a serious problem; are there strong attitudes towards particular control measures and, do different personal experiences with insects influence these attitudes. The survey asked whether respondents had experienced pest infestations, whether they considered insect infestations a serious problem, how well-informed they felt about these pests and their control, and how they wished to see these insects controlled, if at all. Respondents who indicated preference for alternatives to the use of a chemical insecticide were asked whether they would be willing to contribute to a fund to offset the extra cost that might be associated with that alternative.

Our expectation was that respondents from communities affected by jack pine budworm would prefer more aggressive types of infestation control, due to the greater reliance on forests for income generation. In contrast, it was thought possible that respondents from communities affected by gypsy moth might see these infestations simply as a personal nuisance, and be less willing to support the use of pesticides in their community. More informed respondents about either the jack pine budworm or gypsy moth might show an even stronger differentiation, based on their increased awareness of the ecological differences between these two types of insects. On the other hand, it is conceivable that people perceive all insect pests equally - a bug is a bug is a bug (MacDonald et al. 1997). This has important implications for information programs that seek to inform the public about management options.

\section{Jack Pine Budworm and Gypsy Moth}

Both the jack pine budworm and gypsy moth are insect defoliators that can cause dramatic damage to their host trees. Both have also been targets in recent aerial spray programs in Ontario. The jack pine budworm is a native defoliator of jack pine. Outbreaks of jack pine budworm occur mostly in mature jack pine stands in the northern Great Lakes region of Ontario (Nealis 1995). Relatively few people, other than those directly involved with the forest industry in affected areas, have first-hand experience with this insect. However, because the jack pine budworm has a direct impact on tree growth, its control may be perceived as having an economic benefit to northern communities where the forest industry is a major employer. By comparison, the gypsy moth is an introduced insect that feeds on a wide variety of deciduous trees. Unlike the jack pine budworm, which infests a timber commodity, the gypsy moth infests shade and amenity trees in settled areas and often on 
recreational land (Nealis and Erb 1993). The gypsy moth is increasing its range in Ontario. At the time of this survey, outbreaks of gypsy moth had been confined to south-eastern and south-central Ontario, specifically around communities such as Tweed and Bracebridge.

\section{The Survey}

Each questionnaire had a cover letter identifying the senior author and affiliation as well as the purpose of the study. The questionnaire contained a separate section for each of the two forest pests with regard to infestations and pesticide use. All recipients received the same survey. The order of the jack pine budworm and gypsy moth sections of the questionnaire, however, were counterbalanced in all locations to control for order effects.

The first set of questions attempted to establish the level of knowledge of the respondents about the insects. This was followed by factual information about the insects and a brief description of options for control. Appendix 1 contains the information that was provided to respondents concerning the two insects. The second set of questions explored the recipient's attitude about the importance of pest control, their preferences for how to deal with an infestation and the extent to which they felt the community or private citizens should accept the cost of pest control decisions. At the end of the survey, respondents were asked to provide demographic information such as age, sex, education, income level and participation in an environmental group. These questions were used to determine if there were any significant demographic differences among the five communities. The complete questionnaire is available from the authors.

A total of 2050 questionnaires were hand-delivered. If recipients felt they could complete the questionnaire within a few hours, the completed survey was collected personally. If not, the recipients were provided a stamped, addressed envelope with which to return the survey. Reminder notices were not used because of the assurance of anonymity in the cover letter.

\section{Analysis}

With regard to statistical analyses, it must be first stated that this paper takes a descriptive approach. Consequently, the main emphasis was not to construct statistical comparisons (MacDonald et al. 1997), but rather to accurately describe an entire pattern of results. To examine whether or not communities experiencing different pests differed in their attitudes to control of these pests, responses were pooled by jack pine budworm communities (Espanola, Dryden and Kenora) and compared with data pooled from the gypsy moth communities (Tweed and Bracebridge).

There were, however, a number of specific a priori statistical questions that were determined to be of theoretical or practical interest. For these questions, a contrast of two proportions was made using a t-test assessing the equivalence of two proportions. This statistic is distributed as $\mathrm{N}(0,1)$ under $\mathrm{H}_{0}$ (Green and Margerison 1978) and the null hypothesis of no difference was rejected if $t$ exceeded $z(1-\alpha)$. In addition, demographic differences between the two communities were assessed statistically using a chi-square test.

\section{General Results}

Of the 2050 surveys distributed, 1083 or $53 \%$ were completed and returned. The return rates were similar in all communities, ranging from $45 \%$ in Kenora to $60 \%$ in Espanola.
Most respondents completed both sections of the survey irrespective of whether they had personal knowledge or experience with the two insects. This response rate was higher than similar surveys concerning pesticide use (e.g., Roden and Surgeoner 1984; Wellman et al. 1980). Wellman et al. (1980) and Hammitt and Macdonald (1982) showed that follow-up surveys of non-respondents resulted in no or only small changes in results when the initial delivery obtained a return rate of $30 \%$ or higher.

Respondents who reported being "not at all" informed about an insect were the least willing to answer other questions about that insect. These respondents typically had a nonresponse rate to specific portions of the questionnaire that was twice as high as other respondents. However, even the response rate of uninformed respondents was quite high; nearly $80 \%$ for most questions asking about the insect control, indicating that even admittedly uninformed respondents had an opinion about insect control.

Responses to the demographic questions inquiring about participant age, sex, education, income level, number of years lived in the community and environmental group membership were compared among the five communities. There were no significant differences among the five communities with regard to age, sex or education. However, there were slight differences between communities in respect to environmental group membership and income level with a greater proportion of respondents from Tweed and Kenora identifying themselves as members of environmental groups $\left(\chi^{2}=9.85, P<0.05\right)$. In addition, respondents from Espanola were more likely to be from the lowest income group $(\$ 0-9,999$ per year) as well as from the highest income group (over $\$ 50,000 ; \chi^{2}=52.04, P<0.001$ ).

An overwhelming majority of the respondents (961 of 1083 ) had heard of at least one, and many (568 of 1083) had heard of both of the insect pests. Overall, more respondents $(86 \%)$ had heard of the gypsy moth than of the jack pine budworm $(67 \%)$. This could be due to media attention that has focused on gypsy moth in the past. The greater familiarity with gypsy moth may be an artifact of the potential for nonspecialists to mistake forest tent caterpillars (Malacasoma disstria Hubner) for the gypsy moth. Tent caterpillars have been very prevalent in all regions of Ontario during the five years preceding the survey. Evidence that this confusion occurred can be found in the responses to the question pertaining to observed infestations on the respondent's property. A total of 97 respondents (17\%) from northern communities claimed to have observed gypsy moth infestations on their properties despite the fact that no defoliation by gypsy moth has ever been mapped for those communities. Fifty-three of these positive respondents were from Espanola and it is possible that these people had property in infested areas immediately to the south of Espanola but this argument cannot be used to explain the 44 respondents from Dryden and Kenora who claimed to have seen gypsy moth on their properties. In contrast, only 21 respondents from the southern Ontario communities (Bracebridge and Tweed) claimed to have had a jack pine budworm infestation on their property. Given the known range of jack pine budworm, observations in these areas are possible.

\section{Insect Awareness?}

In assessing how aware respondents were of the two insects, responses were pooled from communities previously affected by jack pine budworm (Espanola, Dryden and Kenora) and 
Table 1. The following table represents responses to a pest management questionnaire conducted in five Ontario communities that had been previously affected by gypsy moth infestations (GM towns) or by jack pine budworm outbreaks (JPB towns). In each cell, the percentage of respondents who responded affirmatively to each question is displayed

\begin{tabular}{|c|c|c|c|c|c|c|}
\hline \multirow[b]{2}{*}{ Question } & \multicolumn{3}{|c|}{ Gypsy moth } & \multicolumn{3}{|c|}{ Jack pine budworm } \\
\hline & $\begin{array}{c}\text { GM } \\
\text { Towns }\end{array}$ & $\begin{array}{c}\text { JPB } \\
\text { towns }\end{array}$ & $\begin{array}{c}\text { All } \\
\text { towns }\end{array}$ & $\begin{array}{l}\text { JPB } \\
\text { towns }\end{array}$ & $\begin{array}{c}\text { GM } \\
\text { towns }\end{array}$ & $\begin{array}{c}\text { All } \\
\text { towns }\end{array}$ \\
\hline Heard of insect & 99.3 & 77.3 & 86.3 & 82.9 & 43.8 & 67.1 \\
\hline Seen a small infestation (less than 1 mile in size) & 30.3 & 20.6 & 24.6 & 25.7 & 9.4 & 19.3 \\
\hline Seen an infestation as large as $1-2$ miles & 44.0 & 14.2 & 26.6 & 27.8 & 2.7 & 17.9 \\
\hline Experienced an infestation on personal property & 62.5 & - & & 21.5 & - & \\
\hline Feels fairly informed about insect & 43.7 & 14.7 & 26.6 & 27.9 & 8.7 & 20.2 \\
\hline Feels very informed about insect & 12.9 & 2.8 & 6.9 & 5.3 & 1.5 & 3.8 \\
\hline Feels the insect is somewhat of a problem & 40.3 & 23.8 & 30.6 & 24.7 & 17.8 & 21.9 \\
\hline Feels the insect is a serious problem & 42.3 & 25.3 & 32.3 & 49.8 & 12.5 & 35.1 \\
\hline Feels the insect is a nuisance & 87.7 & 65.6 & 75.3 & & & \\
\hline Reports income is slightly affected by infestation & 11.9 & & & 15.7 & & \\
\hline
\end{tabular}

compared to responses from communities (Bracebridge and Tweed) previously affected by gypsy moth. In addition, awareness of jack pine budworm and gypsy moth was compared across all respondents. Questions designed to assess familiarity included those inquiring about whether respondents had seen an infestation, whether they had been affected by the infestation and how informed they reported being about an insect. Awareness about insect infestations was related to experience. In communities near forests that had been affected by jack pine budworm, approximately $83 \%$ of respondents had heard of the insect. Many of these respondents (54\%) claimed to have seen a jack pine budworm infestation. Nonetheless, many of the respondents in communities that had been affected by jack pine budworm did not feel well informed about this insect $(43 \%$, or 250 of 587 respondents) while $33 \%$ (195 of 587 respondents) felt fairly or very well informed.

In contrast, almost all $(99 \%, 406$ of 409$)$ respondents from communities that had previously been affected by the gypsy moth, had heard of the gypsy moth, despite the fact that only $44 \%$ of respondents claimed to have seen infestations. Approximately $81 \%$ (325 of 403) of respondents reported being fairly or very well informed about the gypsy moth.

Overall, then, respondents in communities affected by gypsy moth appear to be more familiar with the insect affecting their community even though a minority of them had direct, personal experience with the insect. This higher level of awareness is perhaps related to the wide exposure the gypsy moth has received by local media in these communities. Extensive media reports such as those occurring when the Asian gypsy moth was discovered in Vancouver, would increase the likelihood of people noting information concerning the gypsy moth. Further evidence of gypsy moth notoriety is that most people in jack pine budworm communities had heard of the gypsy moth $(77 \%)$ while the reverse was not true; only $44 \%$ of respondents from gypsy moth cities had heard of the jack pine budworm. Increased public familiarity with gypsy moth relative to jack pine budworm may also reflect the fact that jack pine budworm outbreaks occur in forest types far removed from settlements whereas gypsy moth is a pest of shade and amenity trees. A summary of people's knowledge about and general attitudes towards the two insects are presented separately for communities affected by jack pine budworm and the gypsy moth in Table 1.

\section{Are Insect Infestations a Problem?}

Respondents were also asked about whether they considered each insect infestation a problem and whether they felt such infestations affected their incomes. Here again, respondents were pooled on the basis of previous experience, jack pine budworm versus gypsy moth communities. In addition, respondents were pooled on a location by location basis to consider differences that might exist between individual communities.

In communities affected by jack pine budworm, 50\% (291 of 584) of respondents viewed these infestations as a serious problem. Among these communities, perception of the problem was influenced by the degree to which people felt the pest threatened their incomes. In Espanola, 58\% of the respondents felt the jack pine budworm was a serious problem and, at the same time, $47 \%$ felt their livelihood was threatened by the infestation. At the other extreme, in Kenora where only $39 \%$ of the populations felt the budworm affected their incomes, only $29 \%$ viewed the insect as a serious problem. In fact, in jack pine budworm communities, $88.7 \%$ of those who stated that their incomes were affected by jack pine budworm infestations described such infestations as a serious problem, compared to only $43.7 \%$ of respondents who stated that their incomes were not impacted by such outbreaks.

The response from communities affected by gypsy moth were not very different. In Tweed and Bracebridge, $42 \%$ of the respondents felt the gypsy moth was a serious problem. However, only $12 \%$ of the respondents reported that the gypsy moth negatively affected their incomes. Once again, it may be that increased media reporting of gypsy moth influenced people's perception. An interesting difference in attitudes was that those with personal experience of gypsy moth infestations were only slightly more inclined to see the gypsy moth as a problem ( $49 \%$ 


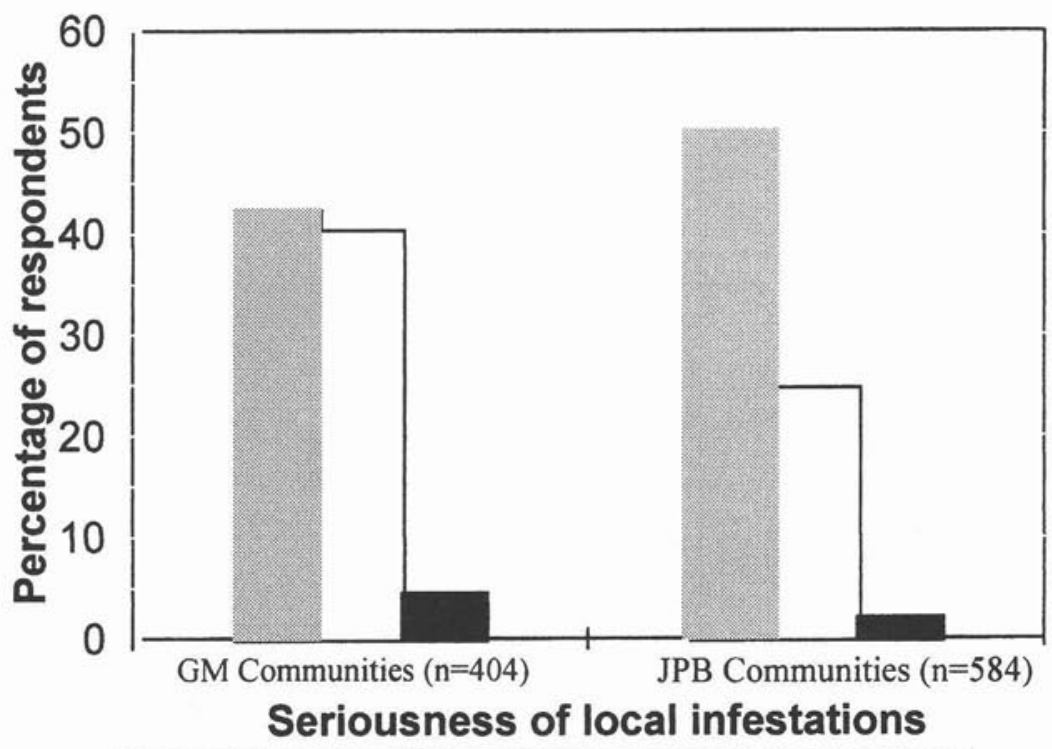

Serious Problem $\square$ Slight Problem $\square$ Not a Problem

Fig. 1. Results of a survey of 1083 Ontario residents with regard to how serious a problem local gypsy moth (GM) or jack pine budworm (JPB) infestations are considered.

versus the overall percentage in gypsy moth communities of $42 \%$ ) whereas most respondents ( 129 of 159 or $76 \%$ ) who had personally seen a jack pine budworm infestation perceived this insect as a serious pest

\section{Attitudes Toward Control?}

Communities affected by gypsy moth were more in favour of letting infestations run their course with no controls (gypsy moth infestation, $24 \%$; jack pine budworm infestation, $20 \%$ ) than respondents in communities affected by jack pine budworm (jack pine budworm infestation, $13 \%$; gypsy moth infestation, $13 \%$ ). Communities affected by the gypsy moth were also less likely to prefer some type of pesticide control of the invading insect (Bt, $45 \%$; carbaryl, 7\%) compared to communities affected by the jack pine budworm (Bt, $57 \%$; carbaryl, $14 \%), z=4.17, P<001$. Of those respondents favouring controls, Bt was preferred as a means to control both jack pine budworm and the gypsy moth (Fig. 2).

The preference for using an insecticide increased as respondents had greater exposure to insect infestations. In northern Ontario, 127 of 149 respondents $(85 \%)$ who had seen a large jack pine budworm infestation were in favour of some type of pesticide for use on this insect, compared to 107 of 139 respondents $(77 \%)$ who had seen only a small infestation and 266 of 582 respondents (53\%) who had not seen any infestation. In southern Ontario, this difference was smaller; 109 of 176 respondents $(62 \%)$ who had seen a large gypsy moth infestation were in support of some type of spray, whereas 64 of 116 respondents $(55 \%)$ who had seen a small infestation and 202 of 394 respondents $(51 \%)$ who had seen no infestation were in favour of some type of spray. In addition, $98 \%$ of northern Ontarians who reported that their income was seriously affected by the jack pine budworm favoured some type of spray compared to $80 \%$ and $67 \%$ of respondents whose incomes were slightly or not affected by the infestation, respectively. In south- ern Ontario, the few respondents (4) who reported that their income was seriously affected by the gypsy moth were undecided as to whether to let the infestation run its course or to spray using Bt.

The influence of experience leading to a greater preference for some type of pesticide control was not the same for both insects. Greater experience with gypsy moth did not necessarily lead to a preference for more control. In fact, as will be described later, respondents who were more informed about the gypsy moth were less inclined than other respondents to use some type of pesticide. The nature of the gypsy moth, however, makes it less likely that respondents would be as heavily dependent on local forest health as jack pine budworm respondents.

\section{Should Communities Subsidize More Expensive Management Options?}

Respondents were asked if they were willing to pay extra costs incurred by using a biological pesticide such as Bt. Overall, respondents were split over whether communities affected by insect infestations should finance more expensive, yet preferred, pest management approaches. A slight majority of respondents who had experienced a jack pine budworm infestation (497 of 857 respondents, or $58 \%$ ) felt that communities affected by jack pine budworm should not subsidize additional costs incurred by using Bt.

However, a slight majority of people in towns affected by the gypsy moth ( $52 \%$, or 189 of 362 respondents) felt that communities affected by gypsy moth should accept the extra cost associated with Bt. Respondents were also asked if communities affected by an insect infestation should accept any indirect costs that might result from a decision to let an infestation run its course, such as lost income or reforestation costs. Overwhelmingly, respondents in all communities were opposed to the idea of financing indirect costs incurred by eliminating spraying. Among respondents affected by jack pine bud- 

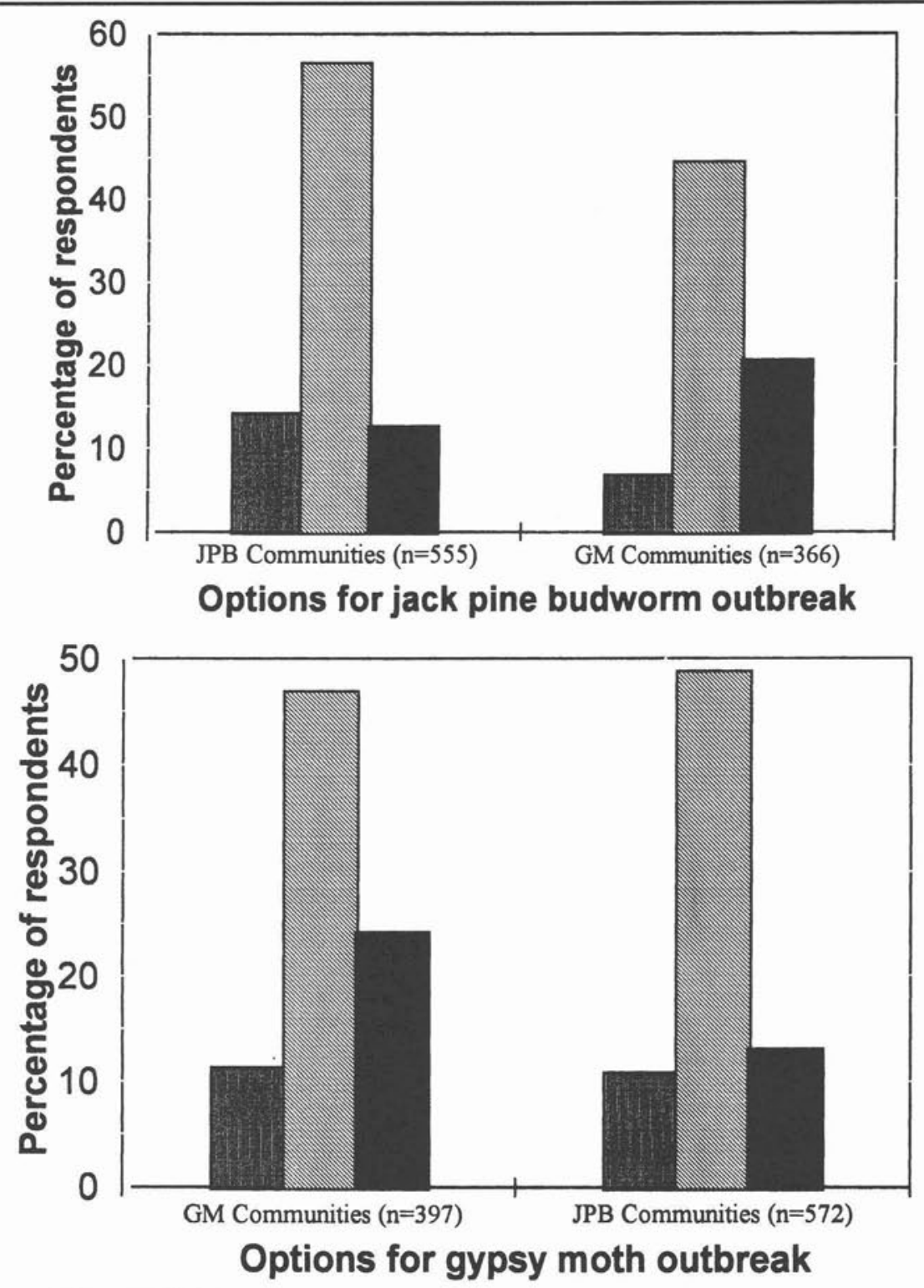

\section{Chemical Spray Biological Spray $\square$ No intervention}

Fig. 2. Preferences of survey respondents from communities previously affected by gypsy moth (GM) or jack pine budworm (JPB) infestations for three management options in response to a gypsy moth or jack pine budworm outbreak.

worm, 414 of 495 respondents (84\%) disagreed with financing any costs incurred by allowing the jack pine budworm to run its course. Similarly, over $81 \%$ of affected respondents $(285$ of 350 respondents) indicated that they did not support subsidization of indirect losses due to gypsy moth infestations.

\section{How Respondents Viewed Insects not Affecting their Community}

All respondents were asked about both the jack pine budworm and the gypsy moth, even though most would have experienced at most one type of insect infestation. This allowed for some cross-comparisons on respondents' views about insects that affect their own community and insects that do not.
Respondents from gypsy moth communities, the majority of whom had not heard of the jack pine budworm, were less likely to favour any type of pesticide on a jack pine budworm infestation than were respondents from jack pine budworm communities. Over $51 \%$ of respondents in gypsy moth communities favoured a biological or chemical pesticide on a jack pine budworm infestation compared to $71 \%$ of respondents from jack pine budworm communities. Interestingly, slightly more people from gypsy moth communities were willing to pay for the extra costs associated with the use of $\mathrm{Bt}$ on a jack pine budworm outbreak ( $46 \%$ ) compared to respondents from jack pine budworm communities (40\%). This is consistent with the tendency of respondents from gypsy moth commu- 
nities to favour "less invasive" management options in their own communities.

Respondents from jack pine budworm communities also tended to express similar attitudes towards the two insects in the survey, despite the fact that only the jack pine budworm had infested local forests. Similar proportions of respondents from jack pine budworm and gypsy moth communities preferred either chemical or biological sprays to combat a gypsy moth infestation (see Fig. 2). However, respondents from jack pine budworm communities were less likely to prefer letting a gypsy moth infestation run its course (13\%) compared to respondents from gypsy moth cities (24\%). This appears to reflect the slightly more active approach to infestation control advocated by jack pine budworm communities compared to gypsy moth communities. Overall, it appears that respondents generally did not differentiate between an insect that had in the past affected their community and one that had not. To some extent, this may reflect ignorance about an insect not known locally.

Specific public awareness campaigns may account for variability in the perceived seriousness and preferences for control options. Within the jack pine budworm communities, more respondents from Espanola (88\%) were aware of the insect than in Kenora (74\%). The greater reported awareness of the jack pine budworm in Espanola may be related to the public awareness campaign conducted by E. B. Eddy Forest Products in Espanola. Respondents from Espanola were also more likely to view jack pine budworm as a serious problem (58\%) compared to those from Dryden $(51 \%)$ or Kenora $(29 \%), z=$ $3.63, P<0.0001$. This perception may have been related to economic factors. Respondents from Espanola were more likely to report that their income was slightly $(19 \%)$ or seriously (14\%) affected by the jack pine budworm, compared to Dryden (14\% and $7 \%)$ and Kenora (9\% and 3\%), respectively. The importance of information campaigns over direct personal experience in raising public awareness of an issue is also evident in the southern, gypsy moth communities. In those communities, there was little difference in either the level of awareness in the two communities despite the fact that significantly more respondents from Tweed had personal experience with the gypsy moth.

Attitudes were examined between respondents according to how well informed respondents felt they were. Respondents who reported being more informed about an insect, not surprisingly, had more experience with that insect. Of respondents from jack pine budworm communities who reported being informed about the insect, 55\% (92 of 167 respondents) reported having seen a large infestation, compared to $18 \%$ (66 of 362) of uninformed respondents. In gypsy moth communities, 122 of 200 informed respondents $(61 \%)$ had seen a large infestation while only $35 \%$ of uninformed respondents ( 55 of 158) had seen a large infestation. Thus, it appears that more informed respondents may have gained information about an insect from personal experience.

Informed and uninformed respondents regarded the seriousness of jack pine budworm infestations similarly. Nearly $67 \%$ of informed respondents (123 of 184 respondents) and $62 \%$ (157 of 252) of uninformed respondents believed the jack pine budworm was a serious problem. Approximately $30 \%$ of informed respondents (57 of 184) and 35\% of uninformed respondents (87 of 252) felt that the jack pine budworm was a somewhat serious problem, and virtually no respondents informed or otherwise reported that the jack pine budworm was not a problem (in total, 12 of 436 respondents).

Views on the control of jack pine budworm infestations were similar among decided uninformed and informed respondents. A similar proportion of both groups favoured using a biological pesticide to control the jack pine budworm (informed, 67.5 and uninformed, 68\%). Fewer informed respondents favoured allowing the jack pine budworm infestation to run its course ( 21 of 173 respondents, or $12 \%$ ) compared to uninformed respondents (49 of 289 respondents, or 17\%).

Among respondents affected by gypsy moth, there were small differences between informed and uninformed respondents. Among decided respondents, informed respondents were slightly less likely to state that the gypsy moth was a serious problem $(46 \%)$ compared to uninformed respondents $(53 \%)$. In addition, more informed respondents supported letting a gypsy moth infestation run its course $(36 \%)$ compared to uninformed respondents (18\%). More informed respondents were also more willing to use a chemical pesticide on a gypsy moth infestation (15\%) compared to uninformed respondents $(10 \%)$. Thus informed respondents were slightly more receptive to management options other than using a biological pesticide in response to a gypsy moth infestation compared to respondents who identified themselves as less informed.

\section{Concluding Comments}

In these communities, people appeared familiar with both the jack pine budworm and the gypsy moth. Almost $100 \%$ of respondents from gypsy moth communities have heard of this insect. In general people seem to be aware, concerned and opinionated about forest pest management.

With regard to the use of pesticides, there were some differences between respondents with different infestation experiences. "Soft" insecticides were always preferred when controls were thought required. There was an overwhelming preference for a biological spray such as Bt regardless of which community the respondent was from, or how informed the respondent reported being. While people clearly preferred the use of Bt to combat forest infestations, the majority of respondents were firmly opposed to community subsidization of more expensive management approaches. However, a slight majority of residents from gypsy moth areas felt that such communities should help finance extra costs incurred by using $\mathrm{Bt}$. With regard to letting an infestation run its course, over $80 \%$ of respondents were opposed to subsidizing any indirect losses as a result of this option.

There were some differences in attitudes between communities with different insect experiences about other management options. Respondents from communities affected by the jack pine budworm showed a greater preference for a chemical spray whereas respondents from gypsy moth communities were relatively more likely to prefer letting a gypsy moth infestation run its course. This result is not too surprising. Jack pine budworm is associated with more industrial forests while the gypsy moth is found more in populated areas and associated with privately owned and recreational forests.

Overall, the majority of respondents indicated that the question of spraying forest infestations was very important. This result indicates that the question of pesticide use is an issue that will continue to attract public attention. In fact, the question of pesticide use was of interest even to people who were admittedly uninformed about the two insects. Respondents who 
reported that they were not well informed about either the jack pine budworm or the gypsy moth were still willing to answer the majority of questions concerning these two insects. These findings suggest that professionals involved in the forestry sector must integrate pest management and public education. Such efforts at education must be geared towards not only groups that are involved and educated, but also the general public, comprised of many individuals who lack information. We believe information programs need to stress not so much that infestations exist, but a critical assessment of the ecological and economic implications of outbreaks so that the public can develop informed opinions about different insects.

\section{References}

Canadian Council of Forest Ministers. 1995. Defining sustainable forest management: A Canadian approach to criteria and indicators. Natural Resources Canada, Canadian Forest Service, Ottawa.

Green, J.R. and D. Margerison. 1978. Statistical Treatment of Experimental Data. Elsevier Scientific Publishing, New York.

Hammitt, W.E. and C.D. McDonald. 1982. Response bias and the need for extensive mail questionnaire follow-ups among selected recreation samples. J. Leisure Research 14: 207-216.

MacDonald, H., D. McKenney and V. Nealis. 1997. A Bug is a Bug is a Bug: Symbolic responses to contingent valuation questions about forest pest control programs? Canadian Journal of Agricultural Economics 45: 145-163.

Miller, J. and B. Lindsay. 1993. Willingness to pay for a state gypsy moth control program in New Hampshire: A contingent valuation case study. Forest Entomology 1828-37.

Nealis V.G. and S. Erb. 1993. A source book for management of the gypsy moth. Forestry Canada, Ontario Region, Sault Ste. Marie, ON F042-19E/1993E

Nealis, V.G. 1995. Population biology of the jack pine budworm. In Jack pine budworm biology and management. Proceedings of the jack pine budworm symposium, Winnipeg, Manitoba. January 24-26, 1995. W.J.A. Volney et al. (eds.). Canadian Forest Service. Information Report NOR-X-342.

Roden, D.B. and G.A. Surgeoner. 1986. Public concerns about gypsy moth (Lymantria dispar, Lepidoptera: Lymantriidae) in Ontario. Bulletin of the Entomological Society of Canada 18: 58-63.

Wellman J.D., E.G. Hawk, J.W. Roggenbuck and G.J. Buhyoff. 1980. Mailed questionnaire surveys and the reluctant respondent: An empirical examination of differences between early and late respondents. J. Leisure Research 12: 164-173.

\section{Appendix 1}

The following represents information (verbatim) that was presented throughout the pest management questionnaire to facilitate understanding and completion of the survey by respondents.
Description of gypsy moth infestation

- Insect introduced from Europe

- Feeds mostly on broad-leaved trees, especially oak, but also birch, poplar, willow, apple

- May or may not kill tree, but is a stress which affects forest health

- May cause loss of income in tourism-related industries, health problems (e.g., connected with allergies), and lessened attractiveness of recreational areas

Description of jack pine budworm infestations

- Insect native to northern Canadian forests

- Feeds mainly in mature jack pine stands

- May or may not kill tree, but is a stress which affects forest health

- Infestations tend to occur every 8-10 years and last for 2-4 years

- Can cause loss of income in forest-related areas such as logging and tourism

There are a number of ways the gypsy moth could be managed. For example, an infestation could be allowed to run its course, or the insect could be sprayed with one of two types of sprays. Only Bt, the biological spray, is used on Crown (publicly owned) land. On private land, there is also the option of using registered chemical sprays (decided by and paid for by the owner).

\section{Biological Sprays}

(is, or once was, a living substance, or is produced by a biological means such as by plants or microbial organisms).

$\mathrm{Bt}$

- active ingredient is produced by a bacterium which occurs naturally in the soil

- toxic to a restricted group of caterpillars

- apparent consensus that $\mathrm{Bt}$ is relatively harmless to humans

- approximately one third more expensive to apply than most chemical sprays

Chemical Sprays

Carbaryl $\left(\right.$ Sevin $\left.^{\circledR}\right)$ - active ingredient is produced from man-made materials

- toxic to caterpillars, other insects, and some other animals

- normally a single application of the spray is effective

- less expensive than biological sprays 